\title{
Fanilik Üzerine Yeniden Düşünüş
}

Öğr. Gör. Dr. Burçin Ünal

\section{Ozet}

Antik Çă̆lardan günümüze uzanan süreçte, kültürden kültüre farklılık gösteren; mezar taşları, özel lahitler, anıt mezarlar, piramitler, ölüyü gömme, mumyalama, resmini, heykelini yapma hatta ölü bedeni fotoğraflama vb. çabaların hemen hemen hepsinin ölüm ve ölüm sonrası üzerine konuşlanan inanç, ritüel ve düşünüşlerin ürünü olduğu söylenebilir.

Ölümün kaçınılamaz ve ertelenemez olması gerçekliği, bir yandan ölüm sonrası yaşam inanışının ortaya çıkması ve evrenselleşmesinde etkili olurken, diğer yandan ise yaşamın gelip geçiciliğine karşı itici bir güç, bir direnç geliștirerek zamanı daha iyi değerlendirme, daha üretken olma, gelecek zamana itici bir guç, bir direnç geliştirerek zamanı daha iyi değerlendirme, daha üretken olma, gelecek zamana makalenin konusu olan "fanilik üzerine yeniden düşünüş", ölüm temasının farklı alanlarda ölüm ve ölüm sonrası üzerine yaklaşımları, ölümlü olmanın bilinci ve problematiği bağlamında ele alınarak, geçicilik(fanilik) etkisinin çağdaş sanata yansımaları -bu alanda çalıșmaları olan sanatçılar ve yapıtları- çerçevesinde irdelenerek, değerlendirilmektedir.

Anahtar Kelimeler: Ölüm, Ölüm Sonrası, Fanilik Bilinci, Sanat ve Geçicilik, Sonsuzluğu Düşlemek

RETHINKING ON MORTALITY

\section{Abstract}

In the process of extending from ancient times to daily, almost all of works/efforts that are tombstones, private sarcophagi, monumental tombs, pyramids, burial, mummification, painting and sculpture of dead body, even dead body photographing etc. with their communal, cultural, time-wise differences can be said to be products of beliefs, rituals and thoughts that are based on death and post-mortem. The fact that death is inevitable and cannot be postponed, on the one hand, becomes effective in the emergence and universalization of the belief of post-mortem life. On the other hand, it is a propulsive force against the passing of life, a better evaluation of time by developing resistance and by being productive. In that respect, it has also been effective in bringing about different creations on behalf of generating something permanent. This article's issue, "rethinking on fanaticism", on behalf of generating something permanent. This article's issue, "rethinking on fanaticism",
evaluates the effects of being transient (temporal) on contemporary art- the artists and works of this field- by considering the approaches on death and post-mortem in the context of consciousness and problematic of being mortal.

Keywords: Death, Post-Mortem, Consciousness of Mortality, Art and Temporality, Dream of Infinity 
Insanlık tarihi boyunca gizleri ile büyük bir muamma olarak ele alınan, çözümlenemeyen yegane sorunsalı, değişmezidir ölümlü olmak. Buna bağlı olarak gelişen ölümlü olma bilinci ise faniliğin, sınırlı yaşamsallık üzerindeki kontrolü, baskısı ve beraberinde getirdiği kaygı, yok oluş, hiçlik, acı, yas gibi duyguların yadsınması ya da içsel zorunluluktan kaynaklanan bir olumlamanın gerekliliğini de çoğu zaman beraberinde getirir.

Ölüm ve ölümden sonraki yaşam hakkındaki inançlar kültürden kültüre farklılık göstermesine rağmen, özellikle eski kültürlerde ölen kişiye veda etmek, onu onurlandırmak veya atalarının anılarıı canlı tutmak adına sembolik yaratımlar içerir. Bu yaratımlar ağırlıkı olarak anma, hatırlatma amaçlı temsili formlar ve heykellerin yanı sıra ölüm sonrası farklı inançlara bağlı olarak ritüel objelerden, ölen kişinin bedenini muhafaza amacıyla özel inşa edilen mezarlara ve mezar içindeki kişiye özel eşyalara kadar farklılık gösterir. Hayatın sonlu olmadığı fikrini açık eden en önemli göstergelerden biri de defin sırasında mezar içine yerleştirilen eşyaların bir kısmının, kişinin yaşarken kullandığı eşyalar veya diğer tarafa yapılan yolculuğunda ona yardımcı olacak işlevsel eşyalar olmasıdır. Ölene ait tüm bu içerenler aynı zamanda kişinin nasıl yaşadığı, nasıı gömüldüğü hakkında hatta hayattayken gücünü ve zenginliğini gösteren bir tür belgelemenin de günümüze aktarılması adına önemli doneler içerir.

Çoğu eski kültürde (İnkalar, İskitler) olduğu gibi Antik Mısır'da da, ölümün hayatın sonu olmadığına fakat yeni bir hayata geçiş olduğuna inanılmaktadır. Bu amaçla bedenin diğer yaşama hazırlanması ve korunması, sonraki hayatta beden-ruh ilişkisinin bağlantısı için çok önemlidir. Bedenin korunma işleminin bu denli önemli olması, öldükten sonra ruhun hâlâ yaşamaya devam etmesi ve bedenin de ruhun evi olduğuna inanmalarından kaynaklanmakta ve bu amaçla da ölüye mumyalama işlemi uygulanmaktaydı (Görsel 1). "Klasik Antik Çağda, muhtemelen M.Ö.4000 öncesi en büyük ölçülerde mumyalamayı geliştiren ve onu 30 yüzyıldan fazladır kullanan eski dünya kültürü antik Mısırdır" (Bajracharya ve Magar, 2006:555). Mumyalama işlemi bittikten sonra beden özenle, özel tabutlara yerleştirilir, ruhun bedeni tanıması için tabutun üzerine ölüyü betimleyen yüz maskesi veya tasviri yapılır ve son olarak mumya, kurgan adı verilen mezar odalara yerleștirilmektedir.

Farklı kültürlerde de örneklerine rastlanan mumyalar (Şili'deki Chinchorro siyah mumyaları) ve kurganlar görülse de, bunların Antik Mısır'da olduğu gibi sonraki yaşam için beden-ruh ilişkisi gözetilerek yapıldığına dair kesin bir bulgu yoktur ${ }^{1}$. Yine de ölünün ardından ritüelleşen tüm eylemler ve bu eylemlerde kullanılan kişisel veya temsili tasarı nesnelerinin tasvir yeteneğinin gelişmesinde önemli katkı sağladığı söylenebilir. Tıpkı ölünün gömülme şekline ve kültürel/dinsel inanışlara göre, geçmişten günümüze ulaşan lahit, kurgan, ziggurat, piramit ve anıt mezar çeşitlerinin mimarideki gelişimin birer göstergesi olması gibi.
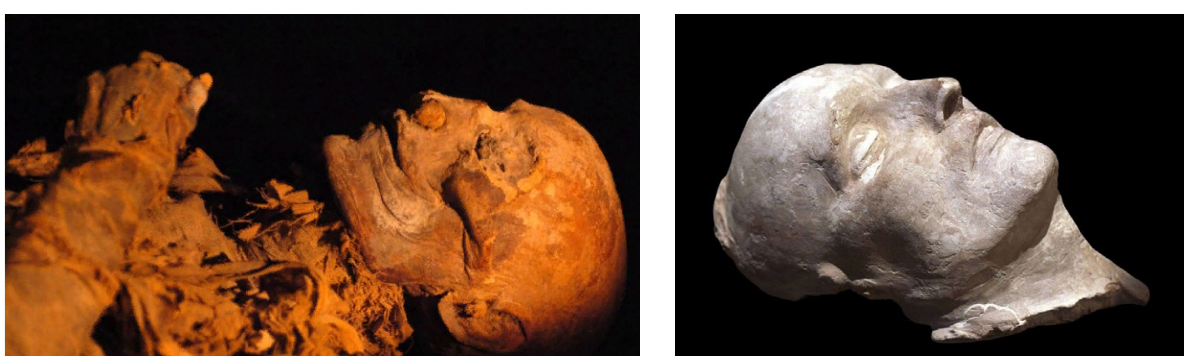

Görsel I. Kraliçe Hatşepsut 'un Mumyası, M.Ö. 1458 tarihine ait, 1903,Krallar Vadisi(bulunuşu) (Solda)

Görsel 2. François Carlo Antommarchi, Napoléon'un Ölüm Maskı, Musée de l'Armée, Paris. (Sağda)

Ölen kişiyi sonsuz kılmak, gömüleceği yerden, gömülme şekline, gömülürken ölü bedene yapılan tüm işlemlere kadar hem ölen hem de -ardındakiler- yaşayanlar için her daim ölüm sonrası kalıcılık arayışlarını içerir. Özellikle ölen kişinin yüzünü tarihe aktarmak temsili olarak kalıc kılmak da bu arayışlardan biridir. Bu amaçla sadece mumyalama değil, ölüm maskesi de bir o kadar eskiye tarihlenir. "Ölüm maskesi, malzemesi balmumu veya alçı olan, ölen kişinin yüzünden alınan kalıptır. Mısır'da portre heykeltraşlarına yardımcı olarak hizmet sunan ölüm maskeleri son birkaç yüzyıldır ölünün hatırasını saklı tutmak için kullanılmaktadır². Mısır'da, Antik Roma'da ölüm maskeleri, farklı tekniklerle de olsa kimi zaman ritüelin zorunlu bir parçası, kimi zaman da temsili olarak kullanılmaktaydı. Ortaçă̆ insanlarında da benzer şekilde mask uygulamaları devam etmesine rağmen özellikle İngiltere'de, “...kralların, kraliçelerin ve diğer önemli şahsiyetlerin ölümü üzerine, maskeleri yapılır, gerçeğe yakın temsili şekilde giydirilir, sokaklar boyunca taşınarak tam da Romalıların yaptığı gibi teşhir edilirdi" (Gibson, 1985:1785). 13. yüzyıldan

' http://www.nationalgeographic.com.tr/makale/kurutulmus\%2C-tuzlanmis\%2C-batakliga-atilmis-mumyalar/2723

https://www.britannica.com/topic/death-mask 
bu yana mezarlarda ya da ölenin temsilini içeren büst ve heykellerde ölüm maskeleri heykeltıraşlar için bir hayli yardımcı unsur haline gelir. Ancak Antik Çă̆'da, Ingiltere ve Fransa'da sadece kraliyet ailelerinin cenazelerinde gerçek ölüm maskeleri kullanılmaktaydı. Ingiltere'de III. Edward'ın maskı en eski Avrupa örneği olarak bilinirken, Fransa'da bu sayının çok az olmasının baş nedeni Fransız ihtilali sırasında çoğunun yok edilmiş olmasından kaynaklanır ${ }^{3}$. Zaman içinde ölüm maskeleri ruhani inanış ya da cenaze ritüelinin ayrılmaz bir parçası olmaktan çıkarak ölenin son hatırası -bir zaman yaşamış olmasının- izlerini taşıyan yegâne kalıntı olarak görülmeye başlanır (Görsel 2). Rönesans ve sonrasında ise ölüm maskeleri yaygın bir şekilde yerini siparişe dayalı muazzam gerçeklikteki yağlıboya portrelere bırakır. Bu portreler öyle canlı ve gerçekçidir ki tıpkı bir fotoğraf gibi detaylandırılır ${ }^{4}$. Fakat asıl çığır açıc yenilik fotoğraf makinesinin icadı ile yaşanır. Post-mortem fotoğraflar (hatıra portresi veya memento mori olarak da bilinen), fotoğrafın icadıyla memento mori (ölümü hatırla) temasını tekrar günceller ${ }^{5}$ (Görsel 3-4). Post-mortem fotoğrafçıllğın hayata girmesi ve kısa sürede hızla yaygınlaşmasında en önemli rol, muhtemelen ölümün evrensel, yadsınamaz bir gerçeklik barındırmasıdır. Kronolojik olarak el alınacak olursa;

Post-mortem fotoğraflar ilk kez Viktorya döneminde Ingiltere' de görülür. Daha sonra Avrupa'nın geri kalanına ve Amerika Birleşik Devletleri'ne yayılır.(....)Bugün, ölülerin fotoğraflarını çekme pratiği negatif çağrışımlara sahipken, Viktorya çağında, onların anılarına gerçek bir saygı duruşunu temsil etmekteydi. (....)Paradoksal olarak bu post-mortem fotoğraflar, bedeni çürümeden önce, "ölünün",son "yaşam resmini" elde etmek için bir şans sunmaktaydı. (Borgo, Licata, ve lorio, 2015: 104)

Fotoğrafın ilk başarılı biçimi olan daguerreotype ${ }^{6}$, ayrıntılı bir resim ve başlarda pahalı bir lüks olarak görülürken bu buluşun yaygınlaşmasıyla, fotoğraf maliyeti ve haliyle ücretinde de düşüşler olur. Bu da; ölünün yakınlarının yağlı boya portrelerini yaptırması veya fotoğrafın sağladığı imkânlardan faydalanmayı sadece soyluların sahip olduğu bir ayrıcalık

\footnotetext{
${ }^{3}$ https://www.britannica.com/topic/death-mask ${ }^{2}$ https://www.britannica.com/topic/death-mask ${ }^{4}$ https://science.howstuffworks.com/science-vs-myth/afterlife/death-mask I.htm ${ }^{3}$ https://www.britannica.com/topic/death-mask ${ }^{2}$ https://www.britannica.com/topic/death-mask ${ }_{5}^{5}$ http://www victorian-era.org/victorian-post-mortem-photography-html ${ }^{6}$ Daguerrotype (Fr. Daguerréotype): Fotoğrafçıllkta, bir fotoğraf elde etmede kullanılan ilk başarll yöntem ve yöntemin sonucunda ortaya çıan görüntü (Bkz. http://www.milliyetsanat.com/haberler/sanat-terimi/daguerrotype/328). Teknik olarak, gümüs nitratla ıș̆ğa duyarlı hale getirilen bakur levher/sanat-terimi/daguerrotype/328). Teknik olarak, gümüş nitratla sş̧ğa duyarı hale getiriten bakir levhaldern, fotoğrafik görüntü elde etmeyi içerir (Bkz. http://vikimy.com/l-tr/Dagerreyotipi).
}

olmaktan çıkararak, orta sınıf halkın da bu imkânlardan faydalanmasını sağlarve böylelikle fotoğraflama, ölenin resminikalıcıolarak koruyabilmenin tek yolu olan portresini yaptırmak kadar pahalı olmaktan da çıkar. Aténé Mendelyté'nin, "Death (in the Eye) of the Beholder: An Encounter with Victorian Post-mortem Photography" isimli makalesinde bahsettiği üzere fotoğraf ve post-mortem fotoğraflar arasında bağlam ve teknik bakımdan farklar vardır.

Herhangi bir sosyokültürel ya da metinsel olarak kodlanmış bilgiden yoksun saf bir psikolojik etki olarak Victorian Post-mortem fotoğrafçllığılla karşılaştırmak elbette estetiksorununu gündeme getirmektedir. Mendelyté, nesnenin tarihi ve bağlamını göz önünde bulundurarak, fotoğraf ve postmortemfotoğrafarasındakinüanslarısıklıklaRolandBarthes'infotoğrafın görüntüsel kalitesinin elzemliği üzerine fikirleri ile bağlantılı kurarak irdeler. Resimler doğaları gereği bir zamanlar nesnenin ölümsüzlüğünü ortaya koyarken diğer yandan ise aslında onun ölümlülüğünün (geçmişliliği) somutlaştırılmasını da görünür kılar. Bu anlamda postmortem fotoğraflarda, fotoğrafın doğallığı görünmez, çoğu zaman yas ritüelinin bir parçası hatta yaslı aile tarafından sonrasında da kullanılan bir tür işlevsellik barındırır. Bu fotoğraflar sadece ölen kişinin temsiliyeti olan bir anma nesnesi ya da onun vasıtasıyla yaşayanlar için üzerinde mevcut bir aidiyet oluşturmanın yolu değil, bir anlamda da öznelleştirme ve temsilin yapılandırmasıyla ihlal halindeki güvenli pozisyonları bir nevî yeniden tahsis edendir (Mendelyté, 2012: 86-90)
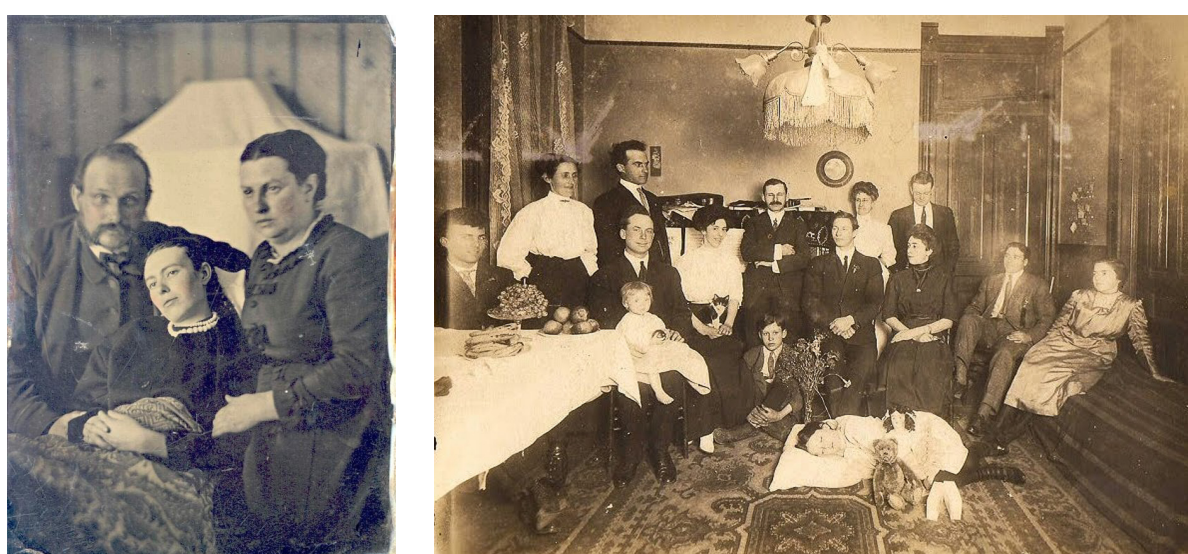

Görsel 3. Kızlarını Kaybeden Ailenin Post-Mortem Fotoğrafı, Victoria Dönemi (Solda)

Görsel 4. Ölen Kız Çocuğu(yerde yatan) ile Ailenin Post-Mortem Fotoğrafı, Victoria Dönemi (Sağda) 
Post-mortem (ölüm sonrası) fotoğraflamanın altında yatan sebepleri, salt olarak fotoğraf makinesinin icadıyla ortaya çıkan yeni bir olgu olarak nitelendirmek doğru bir yaklaşım olmaz. Arketipine bakıldığında ölü bedeni mumyalamaktan, Rönesans ile yağlı boya portrelerinin yapılmasına hatta memento mori (ölümü hatırla) teması ile sanatta bir dönem ayrı bir kategori olarak Vanitas (Latince: "kibir"), adı altında tanımlanmasında da oldukça kült bir yapılanma içerir.

Memento mori (ölümü hatırla), Latince olup, kökeni bir Antik Roma mitine dayanmaktadır. Ancak Antik Çağ insanlarından 20.yy. başlarına kadar ölüm sadece avuntu gereksinimi yaratan depresyon, çöküntü olmaktan ziyade iyi, anlamlı ve erdemli bir hayat sürmek için en güçlü motivasyon kaynağı olarak görülmeye başlanır. İnsanlığa ölümlü olduğunu hatırlatan semboller, simgeler, yazılar, biblolar, resim ve heykeller, sanatçılar tarafından ölüm temasını içeren varyasyonları çoğaltırken, Avrupa'da özellikle Hıristiyanlar tarafından kiliselerde, mezarlarda ve seçkin büyük mimari yapılarda bu varyasyonlar ön planda tutulur. Vanitas, zamanla, dünya üzerindeki doğal yaşamın, dünyevî zevklerin geçiciliği ve var olan her şeyin bir gün son bulma mecburiyeti üzerine kurulu bir sanat kategorisi haline gelir (Görsel 5). Collins, Sculpture Today isimli kitabında Vanitas'ın sanat tarihsel çıkışı ve günümüzde hâlâ geçerliliğini koruyan bir tema olmasına şu şekilde açıklık getirir;

Zevklerin geçiciliği 15. ve 17. y.y.'lar arasında Avrupa natürmortu, özellikle Hollandalı ressamlar arasında oldukça favori bir konuydu. Vanitas olarak tanımlanan bu tür 'ölümü hatırla' teması ile kırık testiler, çiçekler, meyveler, mumlar, parlak balonlar sıklıkla kullanılan ve insanın ölümlüğüne işaret eden sembollerdi. Günümüzde sanatçılar Vanitas'a yeniden döndüler fakat zamanımıza daha uygun sembollerle, bunlar arasından geleneksel bazıları ise hâlâ kullanılmaktadır. Bir bin yıldan diğerine dönüşen tema onların çağdaş gücünü verebilmektedir(Collins, 2007: 198).

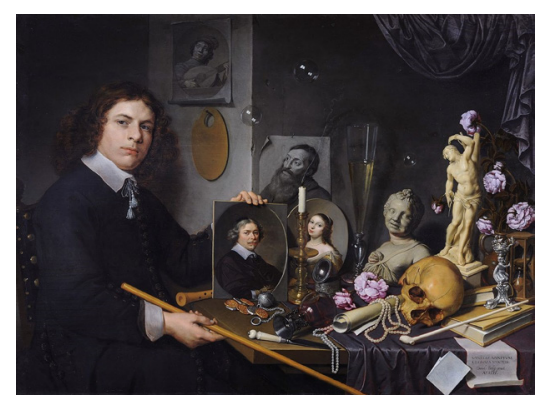

Görsel 5. David Bailly, Vanitas Sembolleri ile Otoporte, I65I, Yağlı Boya Ahşap, 65 × 97,5 cm, Stedelijk Museum De Lakenhal, Leiden
Daha önce olduğu gibi, çağdaş Vanitas uyarlamaları sadece nesnelerle değil, aynı zamanda sembolik olarak -zaman içinde onlara kodlanmışhatıllattıkları benzer düşüncelerle de aynı doğrultuda işler. Yüzyıllar ötesinden çağdaş yaklaşımları arasında sadece bazı farklııklarla; bir yandan yaşamın kısalığı ve tüm dünyevi zevklerin geçiciliğine yeniden vurgu yaparken diğer yandan ise sadece öğreti olarak bir sonraki yaşam üzerine değil, 'gün' içinde yaşamsal verileri yeniden düşünüşü de içeren yaklaşımlar, malzemeler ve pratikler üzerine yoğunlaşır.

Collins, geçicilik etkisini ön plana çıkaran malzeme tercihinde organik ve çürümeye referans veren sebze, meyvelerden, anlık etkileşim yaratan veya tepkimeye giren kimyasal maddelere, kısa ömürlü; ateş, duman, barut kullanımından parfümün uçuculuğuna kadar farklı kullanım ve ifade olanakları olduğundan bahseder. Arte Poveracıların bir kısmının çalışmalarında organik malzemelerin, yiyeceklerin ve belli besin gruplarının kullanımını yine bu geçicilik etkisiyle ilişkilendirir? ${ }^{7}$. Yaklaşım bakımından da; organik malzemelerle yapılan işler aynı zamanda, süreç ile ilgili fikir verir ve değişim, büyüme, bozulma, tüketim, ölüm gibi kavramları içerir. Ancak ilerleyen yıllarda kullanılan materyallerle çürüme, bozulma süreçlerini kullananların yeniden sadece faniliğe; yeryüzünde canlı olan her şey üzerinde kaçınılmaz bir son olan evrensel gerçekliğe vurgu yaptığı görülür.

1986'da, Helen Chadwick 'Değişkenlik' ismini verdiği karışık yerleştirme ile her şeyin değişmek zorunda olduğu bir dünyada, fiziksel tatminin, sevincin, zevklerin çok hızla son bulduğunu, insanların tüm deneyimlerinin, isteklerinin bir gün bir balon gibi sönmek zorunda kalacağının üstünde duran Vanitas düşüncesini çağdaş bir yaklaşımla yeniden görünür kılar (Görsel 6). Sanatçının karışık enstalasyonunda ön kısmı oluşturan muazzam görüntüyü sağlayan yerleştirmedeki parlak kürelerin arkasından görünen sütunu ise ikinci odada yer almakta olan "Leş" isimli çalışmasıdır (Görsel 7). İki metre yüksekliğindeki cam kule içine yerleştirilen çürüyen bitkisel maddelerden oluşan çalışma, sergileme boyunca kendi sürecini oluşturan, zamanla daha da çürüyerek yer değiştiren ve yeni organizmalar yaratarak organik bir tür gübre halini almaya başlar. Chadwick, cam kule (sütun) içindeki materyallerin seviyesini korumak için her gün çalışmaya müdahale ederek, kontrol altında tutsa da, sergileme sırasında beklenmedik bir şekilde sütunda oluşan çatlak paniğe yol açar ${ }^{8}$. Çatlaktan çıkan atıklar ve

${ }^{7}$ Collins, a.g.e., $198^{2}$ https://www.britannica.com/topic/death-mask

${ }^{8} \mathrm{https}: / /$ alchetron. com/Helen-Chadwick 
sızan kötü koku kısa süre de tüm galeriyi sarar, tıpkı sona gelinen süreçte sonun şimdiki zamana, sonu önceleyen köklerini yavaş yavaş salması gibi.
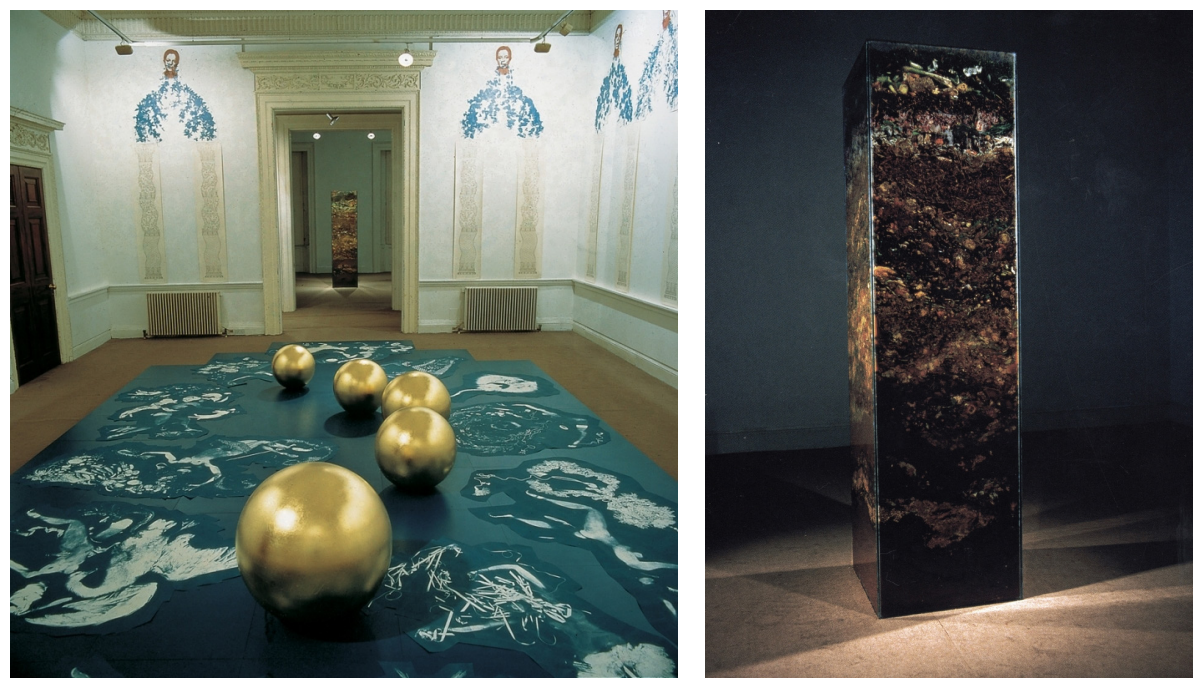

Görsel 6. Helen Chadwick, Değişkenlik, 1986, Enstalasyon (Solda)

Görsel 7. Helen Chadwick, Leş, 1986, Organik malzeme, plexi/cam (Sağda)

Benzer yaklaşımla, James Lee Byars'ın, 1989 heykelinin yeniden kurgulanmasıyla ortaya koyduğu "Gül Tablonun Mükemmelliği" isimli çalısma, yaklaşık olarak 40 inç çapında ve 3000'den fazla kırmızı gülle bezenmiş bir küreden oluşur. Gösterimde iken taze olan güller, sonrasında kuru, kahverengi bir hal alır ve dünyanın en büyük keseciğini andırırken etrafa hafif bir koku verir. Bu anlamda, çalışmada geçicilik, geçişkenlik, evrensellik, mükemmellik ve sonrası gibi kavramlar kendini doğal yollarla hissettirir (Görsel 8). Çalışmanın tam da durduğu, işaret ettiği yer, aslında olmakve ölmek denilen iki uçtaki arada kalan alanı, üzerine asıl düşünülmesi gereken yeri betimler gibidir. Çalışmanın küre şeklinde olması üzerinde yaşanılan yerküreye, güllerin mükemmel dizilimi, görüntüsü ve kokusu mükemmeliyet kavramını o an üzerinden tariflerken, diğer yandan kısa bir süre sonra çürüyerek bozulacağını bilmek de bu olasılığın imkânsızlığını düşündürür.

${ }^{9}$ https://www.nytimes.com/1999/09/03/arts/art-in-review-james-lee-byars.html

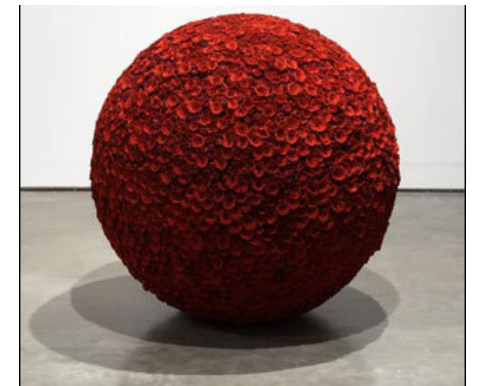

Görsel 8. James Lee Byars, Gül Tablonun Mükemmelliği, 1989, Küre , 3333 Kırmızı Gül

Vanitas tasvirlerinde diğer tüm semboller arasından; ă̆ırlıklı olarak, farklı çeşitlemeleriyle ön plana çıkan sembol kurukafalardır. Bu sembolün çağdaş bir yaklaşımı da Damien Hirst'in; ölüm ve insanları ölümün (teşhirinin) izleyicileri olarak farklı şekilde konumlandırdığı işleridir. Ancak, Hirst'in, ana ilham kaynă̆ını oluşturan ölüm temasını işlediği tüm çalışmaları içinde en ikonik parçası olan 18.yüzyıldan kalma Avrupa-Akdeniz kökenli bir erkeğin orijinal kafatasından alınan platin kalıp üzerine işlenmiş 8601 adet elmastan oluşan "Tanrı aşkına" isimli çalışmasıdır (Görsel 9). Bu çalışmanın, yüksek maliyetle yapılmasının ötesinde olası değerinin çok üstünde fiyatlandırılmasıyla çağdaş sanat piyasasında sansasyonlara da sebep olmuştur ${ }^{10}$.

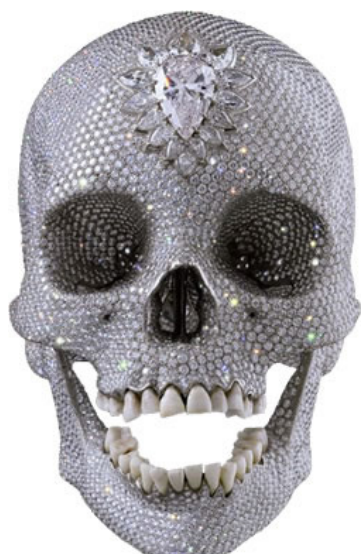

Görsel 9. Damien Hirst, Tanrı Așkına,2007, Platin, elmas, insan diși, 17, Ix|2,7x 19, I $\mathrm{cm}$.

${ }^{10} \mathrm{http}: / /$ content.time.com/time/specials/packages/article/0,28804,2028282_2028286_2028491,00. $h \mathrm{tm}$ 
Sanatçının ölümün temsili formlarından kafatasını bu defa çok çarpıcı şekilde kullanmasından önce de aynı tema ile ilgili çok sayıda çalışması yer almaktadır. Bu bağlamda kurguladığı eskizleri memento gravürlerinde tasvir edilen ölüm hatırlatıcıları işlevini gören kafatasları, dev akvaryumlardaki formaldehitte muhafaza edilen ölü hayvan figürleri, yaşamın geçici doğasını yansıtan çiçekleri, kısa yaşam süreleriyle sadece faniliği değil aynı zamanda yaşam döngüsüne de eşlik eden metamorfoz ve dirilişi temsil eden kelebekleri hepsi birbirini ve ilham aldığı ana hattaki ölüm temasını besler niteliktedir.

Geçicilik/fanilik bilinci, birey yaşamı üzerinde farklı etkilere yol açar, bunlardan ilki değersizleştirme diğeri ise inat ve inanç ile yaşama tutunmaktır. Ölümle ilgili gizin ön plana çıkardığı ölüm korkusu zaman zaman ileri geleceğe (sonsuzluk) dair umut besleme, ölümü yadsıyarak mantığa dayanmayan inançlar veya düşünce sistemi geliştirme ya da yadsımanın en uç örneği olan fikirlere katılma, benimseme şeklinde olabilir. Ölümün, insanlık tarihi boyunca vazgeçilmez ve evrensel bir tema olmasında, ölüm korkusu ve bu korkunun yarattığı çaresizlik oldukça etkilidir. Fakat yaşam süresi boyunca sırf bu korkuyla yaşamak da anlamsızdır, korkunun acımasız yaptırımına kapılıp, yaşamları etkisi altına almasına izin vermenin yerine umudu koymak denenebilir. Fani olma korkusunun yol açtığı yaşamsal yaptııımlara direnmenin başında ise yaşamdan sonra da bir şekilde var olabilme isteği ve tamamen yok olmaya karşı direnç geliştirme gelir ki, çoğu duygulanım, eylem, düşünüş ve üretimin temelinde bu itici güç vardır. Benzer şekildeki görüşü, Victor Brombert, Fanilik Üzerine Düşünceler isimli kitabında şu şekilde dile getirir;

Belki de bütün düşünce ve sanat eylemi kaynağını dolaylı olarak fanilikten alıyordur Bu noktada bir kez daha, doğrulanması mümkün olmasa da André Malraux'nun insanı heyecanlandıran esrarengiz sözleri geliyor akla; mağarasının taş duvarına bizon çizen ilk insan, hem kendisinin hem de bizonun fani olduğunun farkındadır, ama aynı zamanda bu ilk sanatçı fani hayvanı tasvir etmenin bir bakıma "hiçliğimizi yadsımak" anlamına geldiğini de sezmiş gibidir (Brombert, 2016: 215).

Çoğu zaman ölümün karşılığı olarak görülen 'hiçlik'kavramı ise, olumsuzlamanın ötesinde bir öğreti içerme durumu da yaratabilir. Heidegger'e göre hiçliğe, ölüme dair kaygının deneyimlenmesi yoluyla erişim sağlanır ve "Heidegger tarafından ölümün tarifi bir olasılık ortaya koyar, olasılık-olmayanın olasılığı. Hiçlik ölüm içinde düşünülür. Ölümde Heidegger'i büyüleyen şey, hiçliği düşünme olasılığını bulmasıdır" (Levinas, 2011: 69) .
Fakat asıl öğreti, yaşamsal öğretidir yani var olmak ve ölmek arasında kalan o en işler, iki uç arasındaki en geçirgen aralıkta edinilen. Bir canlı için var olmak, ölümlü olmayı da beraberinde getirir tersten bir okumayla döngüsel bir durumdan da bahsedilebilir. Bazı düşünürlerin ölümü hayata anlam yükleme, felsefe ve şeylerin özüyle ilişikilendirmesine karşın Brombert, Friedric Hegel'de ise varoluşsal akış yerine özle ve varlıkla ilişkilendirildiğinden bahseder. "Hegel Mantık Bilimi kitabında kelime oyunu yaparak, Weseni (Oluş), geçmiş zaman kipindeki hâli gewesenle (olmuş), yani çoktan ölmüş olanla ilişkilendirir. Oluş, olmuş olan şeydir" (Brombert, 2016: 214).

Christian Boltanski'nin, ölümü ana tema olarak kullandığı

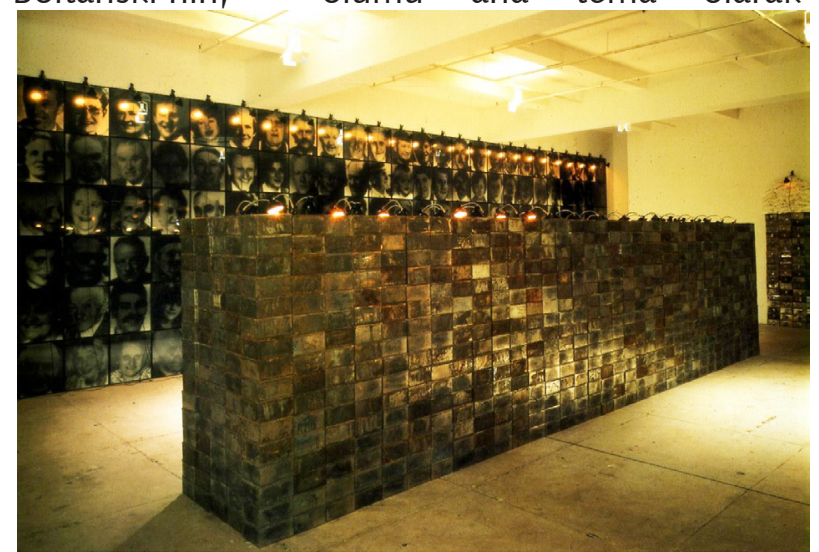

Görsel 10. Christian Boltanski, Ölü İsviçreli Rezervi, 1990, Enstalasyon, Siyah-beyaz fotoğraflar, Metal Kutular, Lambalar

enstalasyonlarından biri olan "Ölü İsviçreli Rezervi", bir zaman var olup sonrasında olmayan ve olandan artakalan kişisel ya da hafizada anısal çağrışımları olan eşyalarla, olayları (döneme veya kültüre ait) kullanarak izleyiciyle yakından ilişki kurar (Görsel 10). Anıtsal özelliği de içinde barındıran duvar şeklinde örülü, metal teneke kutulardan oluşan form, bir tür anıt/mabet etkisi yaratırken, İsviçre'nin günlük gazetesinden temin ettiği ölüm ilanları ve ölen kişilere ait fotoğraflar ardında saklanan sembolik detaylar, çalısmada çok yönlü anlam katmanları yaratır. Metal kutular, sanatçının yaşadığı döneme ait olarak, insanların özel eşyalarını ya da önemli belgelerini saklamak için kullandığı geleneksel bir uygulamaya atıf yapan bisküvi teneke kutularından oluşur. Fotoğrafların, bir zaman yaşamış olan bir insanın temsili yerine geçmesi, fotoğraflara tutulan lambanın ışığının, ölen kişinin ardından anısına yakılan muma mı yoksa sorgu sırasında 
stres/işkenceye maruz bırakmak için kullanılan lambalara mı refere ettiği kestirilemez. Bu anlamda, çalışmada kullanılan her materyal, her formun anlam dağarcığında birbiriyle paslaşan çağrışımlar yarattığı görülür.

Var olmak-ölmek (yok olmak) fiziki bir varlığa işaret etmenin ötesinde ele alındığında, arada kalan yaşam, yaşamayı öğrenmek, gerçek bir var oluş amacına ne derece yaklaşıldığıyla ilgilidir. Tuhaftır ki; oysa ölüm ,ölen kişi için, sonrası öğrenilemeyecek kadar keskindir, o ancak başkasının ölümüne tanıklık eden ikinci, üçüncü şahıslar için bir öğreti, anlam ve asıl deneyimlenenden bağımsız bir gerçeklik içeriyor olabilir. "Ölüm, sadece yaşamayı engellemekle kalmaz, aynı zamanda insanın ölüm olmaksızın bir insan olamayacağını, büyük hayatlar yaratanın, onlara bu şevki, heyecan ve gücü verenin ölümün bu gizli varlığı olduğunu da anlarız. Bu durumda denilebilirki ölmeyen, yaşamaz da" (Jankelevitch, 2012:16). Bir insanın (yakın veya sevilen) ölümüne tanıklık etmek, ölüm ve sonrası üzerine yeniden düşünmeyi ve ondan öğrenilecek, adına paylaşılacak tüm şeylerin de başlangıç noktasını oluşturur.

İsimsiz (Yatak), 1991 isimli çalışma, çalışmalarının çoğunda kayıp, aşk, ayrilık ve ölüm gibi karmaşık temalarla ilgilenen Gonzalez-Torres'in, sevgilisi Ross Laycock (AIDS kurbanı)ile paylaştığı yatağın büyük ölçekli fotoğrafından oluşan ve oldukça kişisel içeriğe sahip bir iştir (Görsel 11). New York'un farklı bölgelerindeki reklam panolarına yerleştirilen görselde iki yastık ve toplanmamış çift kişilik bir yatak bulunmaktadır. Yatakta ve yastıkta kalan bedensel girinti izleri ve kırışıkıklar, hâlâ sıcaklığını ve iki kişiye ait özelin mevcudiyetini koruyan o aidiyet duygusunu "şimdi/ şu an" ve "sonra" ilişkisi üzerinden zarifçe hissettirir. Eşcinsel ilişki, bir kısım tarafından -kabullenilebilir- hoşgörüyle karşılanan bir ilişki olarak tanımlansa da Batı kültürünün çoğunluğunda hâlâ homofobi yaygındır. Sanatçının özelini kamusal alanda ve herkesin görebileceği bir teşhir alanı olan reklam panolarında sergilemesi de bu anlamda hem naif, şiirsel, aşırı duygu yüklü hem de aykırı bir tavır içerir.

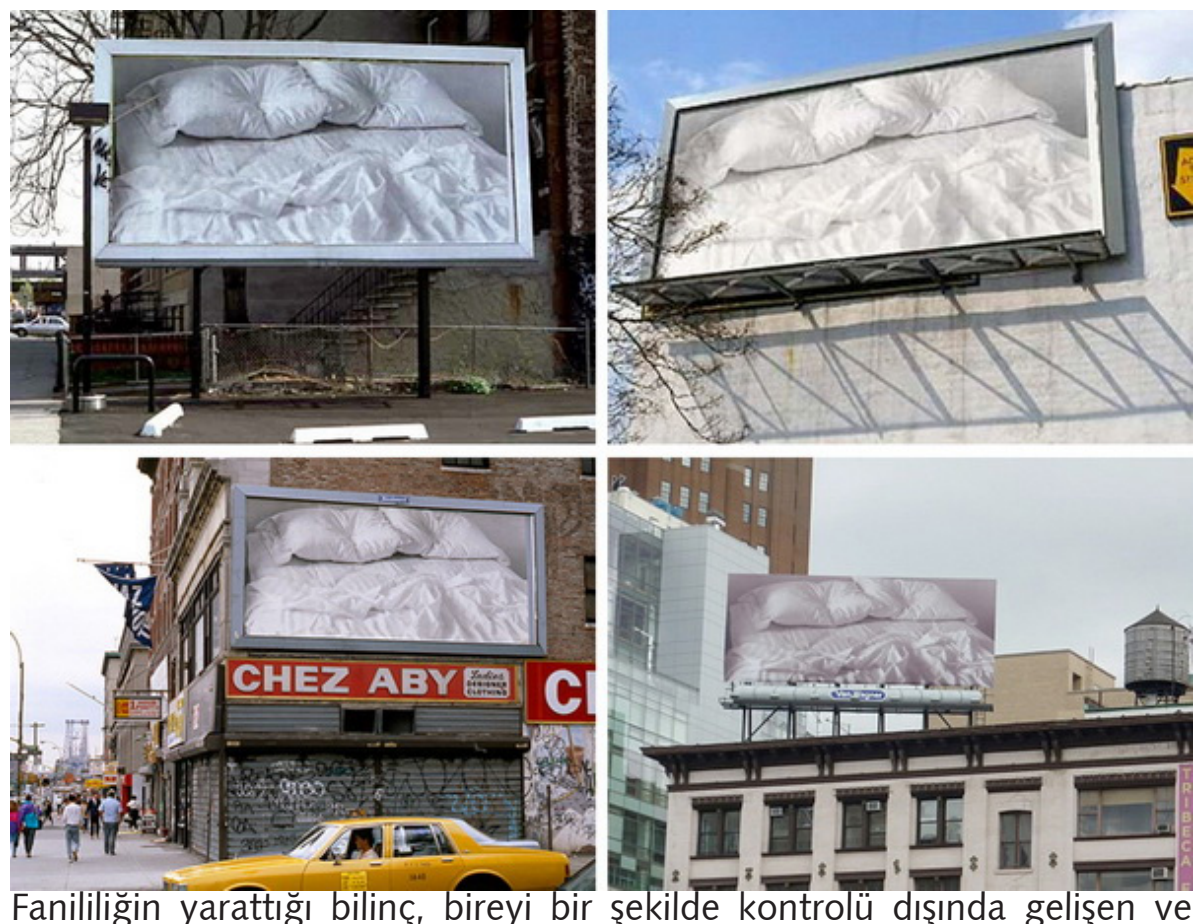

Fanililiğin yarattığı bilinç, bireyi bir şekilde kontrolü dışında gelişen ve
Görsel II Felix Gonzalez-Torres, İsimsiz(Yatak), 199I, Baskı çıtı(Boyutları değisken).

NY

yaşadığı zamanı kuşatan ölüm korkusu ile yüzleşmek zorunda bırakır. Ölümlü olma bilincinin yarattığı bu korku bir zaman sonra kronikleşecek olan kaygı durumunu da beraberinde getirir. Bu durum karşısında tavır ve duygulanım bakımından insanlar iki keskin noktada, uçta durur.

Ölüm duygusu olan insanla bu duyguya hiç sahip olmayan arasında, iletişim mümkün olmayan iki dünyanın uçurumu açılır; bununla birlikte ikisi de ölür; fakat biri ölümden habersizdir, ötekiyse bunu bilir; biri sadece bir anda ölür, ötekiyse sürekli ölmektedir.(...). Biri sanki ebediymiş gibi yaşar; öteki devamlı olarak ebediyetini düşünür ve bunu her düşüncesinde inkâr eder (Cioran, 2016: 15).

Sanatçı Andres Serrano'nun, "Morg", isimli fotoğraf serisi, ölümle ilgili fikirleri ve insanların onunla olan ilişkisini araştııır (Görsel 12-13). Morg ile bağlantılı olamayacak kadar doğal güzellikleriyle fotoğraflanan bedenler ve kişisel gizliliğin korunması adına yüzlerinin örtülmesi (kısmen veya tamamen), anonimliği sağlamanın yanı sıra, ısık-gölge efektlerinin etkili bir şekilde (barok etkisi) kullanılmasıyla da ölümlerin ardındaki gizi 
daha da kuvvetlendirir. Sanatçının, çalışmasında ölümü tüm çıplaklığıyla detayları yumuşatarak gözler önüne sermesine rağmen yine de serideki her çalışmasının ismini ölüm sebebi ile eşleştirerek sunması ise iki uç arasında ironi oluşturur. Çalışmalarda, Serrano'nun kişisel duygusalıktan uzak profesyonel bir şekilde fotoğrafladığı bedenler, onu alımlayanlarda aynı etkiyle karşılık görür mü bilinmez, fakat sanatçının amacı duygusal etki yaratmaktan uzak olsa da, ölüm zaten kendinden korku, acı, hüzün ve ayrılık duygusunu en derininden içerendir.
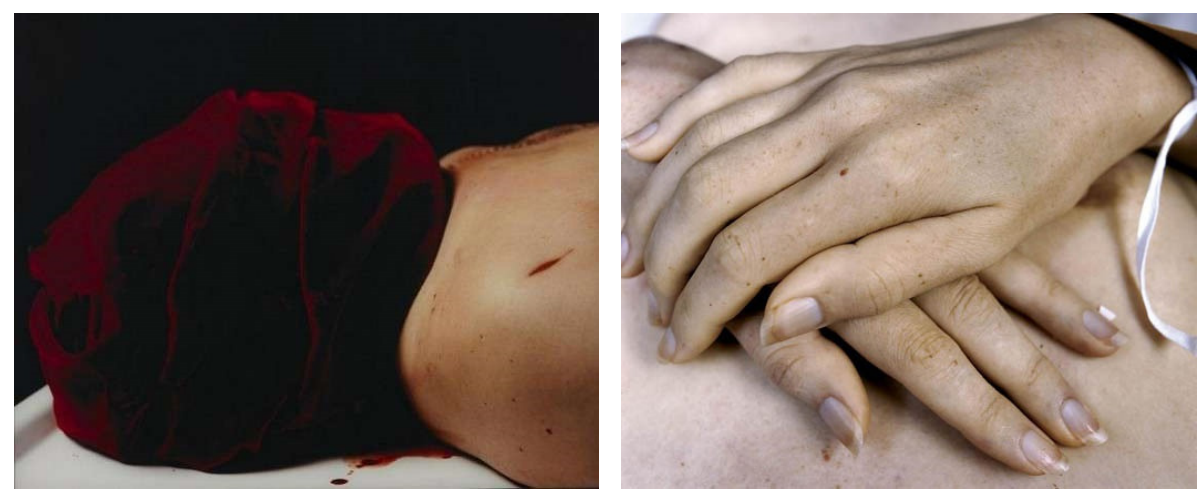

Görsel I2. Andreas Serrano, Morg(Cinayet), 1992, Fotoğraf Baskı (Solda)

Görsel I3. Andreas Serrano, Morg(AIDS ilişskili Ölüm), 1992, Fotoğraf Baskı (Sağda)

Geçici/fani olmanın bilinci, yaşam-ölüm, beden-ruh ilişkisi üzerinden ele alındığında ölümün, beden varlığı ile sınırlı olup olmadığı, tinsel olanın -zihinsel olan ile- bilinçle ilişkilendirildiğinde, bilincin bedensel yok oluştan bağımsız da var olabilirliliğini yeniden ve yeniden düşünmek evrensel bir sorunu, her yeni günün asıl sorunsalı olarak günceller. Bu da, çoğu zaman, ölümün yaşamı sınırladığı, sonlandırdığı, yokluğa ve bazen de hiçliğe işaret etmesinin çok ötesinde muğlâk bir durum olarak ölümden sonra, ölümü deneyimleyen kişi dışındakilerin onun gizemine ulaşamayacağı fikrini güçlendirir. Yine de ölümden sonra beden kadar tinsel olanın, bilincin de yok olacağı ya da varlığını sürdürebileceğine ya da asla sürdüremeyeceğine dair kesin bir veri bulunmamaktadır.

\section{Sonuç}

Ölümü, evrensel hatta, yaşamla ilgili tüm alanlarda baş sorunsal haline getiren en önemli şeylerden biri -muhtemelen- insanoğlunun, ölümlü olmayı özdeşleștirdiği 'hiçlik', 'yok olma' bir daha olmama' durumu ve yaşamını sürekli bu durumu yadsıyarak sürdürmesine rağmen yine de ve sonunda, ölümün çözümlenemeyecek/sonlandırılamayacak olduğunu -yani aslında fani olduğunu- bilmesidir.

Oysaki evrensel geçiciliği kabullenmek, süreli yaşam içerisinde güzel, kusursuz, haz verici ya da önemli bulunan hiçbir şeyi sırf yok olmaya mahkûm olduğu için daha az güzel, keyifsiz ve değersiz hale getirmez. Duygulanım bakımından yok olamayacak kadar eşsiz bulunan 'şeye' atıf, göreceli bir durum yaratır. Eşsizliğinden ve yarattığı etki alanından bağımsız bir şekilde geçici olmaya ve bir daha olmamaya direnen her şeyin, ona yüklenen anlamlar dışında var olmaya devam etmesi-sadece kendi olarak bile- başlı başına mutlak bir değer yaratır. Böylece ister süreli bir ömre sahip insanoğlu ister daha uzun süre evrende kalmayı kendi olarak başaran madde varlıklar olsun, her var olan şeyin bir gün sonlu/yok olacağını bilmek sadece yaşayanlar için yaşamının her anında muazzam bir "ideal zaman" yani "şimdiki zaman" yaratır. Fanilik üzerine yeniden düşünmek; o her şimdiki zamanda, keşfedilmesi için, içinde sadece kişiye özel anlar, planlar, yaptırımlar ve nitelikli bir hayat için fırsatlar saklar ki, fani olmayı bu kadar eşsiz kılan da budur. Diğer bir deyişle; ölümden sonra sonsuzluğa ulaşmak mümkünse bunun kökleri her insan için sınırlı yaşam süresi içinde, o "hâlâ yaşıyor olduğu şimdiki zamanda" saklıdır. 


\section{Kaynakça}

Bajracharya S., Magar A.(2006). Embalming: An Art of Preserving Human Body. Kathmandu University Medical Journal, 4(I6), 555

Brombert,V.(20I6). Fanilik Üzerine Düşünceler-Tolstoy'dan Primo Levi'ye (çev. A.Terzi), Istanbul: Kolektif Kitap

Cioran, E.M.(20/6). Çürümenin Kitabı (çev. H.Bayrı), İstanbul: Metis Yay.

Collins.J.(2007). Sculpture Today. London:Phaidon Press

Gibson, I.I.J.M.(1985, 21 -28 December). Death Masks Unlimited. British Medical Journal, 29I, 1785

Jankelevitch, V.(20I2). Ölümü Düşünmek (çev.Y.R. Demir). İstanbul: MonoKL Yay.

Levinas,E.(20II). Tanrı, Ölüm ve Zaman(çev.I.Ergüden), Ankara:Dost Kitabevi Yay.

Mendelyté, A.(2012/Summer). Death (in the Eye) of the Beholder: An Encounter with Victorian Post-mortem Photography. SYNAESTHESIA Communication Across Cultures.

Communications Journal. I(3), 86-90

\section{Internet Kaynakları}

Daguerrotype. http://www.milliyetsanat.com/haberler/sanat-terimi/daguerrotype/328 , http://vikimy.com/l-tr/Dagerreyotipi (Erişim Tarihi: 29.05.20I8)

Death Mask. https://www.britannica.com/topic/death-mask (Erişim Tarihi: 04.01.2018).

Helen Chadwick. https://alchetron.com/Helen-Chadwick (Erişim Tarihi: 29.05.2018).

Kurutulmuş, Tuzlanmış, Bataklığa Atılmış Mumyalar. http://www.nationalgeographic.com. tr/makale/kurutulmus\%2C-tuzlanmis\%2C-batakliga-atilmis-mumyalar/2723 (Erişim Tarihi: 29.05.2018).

Melania Borgo,M.,Licata,M., lorio,S. (2015). Post-mortem Photography: the Edge Where Life Meets Death?. De Gruyter Open. HSS V.2. https://www.degruyter.com/ downloadpdflj/hssr.2016.5.issue-2/hssr-2016-0016/hssr-2016-00 l6.pdf (Erişim Tarihi: 25. 03. 2018

Smith, R., Art in Review; James Lee Byars. https://www.nytimes.com//999/09/03/arts/ art-in-review-james-lee-byars.html (Erişim Tarihi: 29.05.2018).

Tharoor, I., Damien Hirst's For the Love of God. http://content.time.com/time/specials/ packages/article/0,28804,2028282_2028286_202849I,00.html (Erişim Tarihi: 29.05.2018).

Victorian Post Mortem Photography http://www.victorian-era.org/victorian-post-mortemphotography.html (Erişim Tarihi: 29.05.2018).

Wright, E. ,How Death Masks Works. https://science.howstuffworks.com/science-vsmyth/afterlife/death-maskI.htm (Erişim Tarihi: 29.05.2018).

\section{Görsel Kaynakları}

Görsel I. Kraliçe Hatşepsut 'un Mumyası. http://www.abc.net.au/news/2007-06-27/themummified-body-of-queen-hatshepsut/82932 (Erişim Tarihi: 25.03.2018)

Görsel 2. François Carlo Antommarchi, Napoléon'un Ölüm Maskı. http://www.look4ward. co.uk/weird/death-mask-as-a-way-to-preserve-history-and-breathe-life-into-the-dead/ (Erişim Tarihi: 25.03.20/8)

Görsel 3. Kızlarını Kaybeden Ailenin Post Mortem Fotoğrafı. http://listverse.wpengine. netdna-cdn.com/wp-content/uploads/20/2/I0/Deadgirlwmomsnpops.jpeg (Erişim Tarihi: 25.03.2018)

Görsel 4. Ölen Kız Çocuğu ile Ailenin Post Mortem Fotoğrafı.

https://www.oddee.com/item_98883.aspx/I8/ (Erişim Tarihi: 25.03.20I8)

Görsel 5. David Bailly, Vanitas Sembolleri ile Otoporte, 165I. https://www.wga.hu/ frames-e.html?/html/b/bailly/selfport.html (Erişim Tarihi: 29.03.2018)

Görsel 6. Helen Chadwick, Değişkenlik, 1986. https://theartstack.com/artist/helenchadwick/of-mutability (Erişim Tarihi: 10.04.2018) 
Görsel 7. Helen Chadwick, Leş, 1986. https://theartstack.com/artist/helen-chadwick/

carcass

(Erişim Tarihi: 10.04.2018)

Görsel 8. James Lee Byars, Gül Tablonun Mükemmelliği, 1989. https://theartstack.com/ artist/james-lee-byars/spherical-perfection-the-rose-table-of-perfect-1988 (Erişim Tarihi: 10.04.2018)

Görsel 9. Damien Hirst, Tanrı Aşkına,2007. http://deskarati.com/2012/I0/I2/damienhirst/ (Erişim Tarihi: 13.04.2018)

Görsel 10. Christian Boltanski, Ölü İsviçreli Rezervi, 1990. http://astropartner.su/ painters/Boltanski.html (Erişim Tarihi: 13.04.2018)

Görsel I I. Felix Gonzalez-Torres, İsimsiz (Yatak), 199I. http://designs.vn/tin-tuc/-traoluu-nghe-thuat-nghe-thuat-vi-niem-conceptual-art-la-gi-_I6704.html\#.WszrNLRWr58 (Erişim Tarihi: 13.04.2018)

Görsel 12. Andreas Serrano, Morg (Cinayet), 1992. http://www.beautifuldecay. com/20/3/09/13/andres-serranos-powerful-images-death/ (Erişim Tarihi: 13.04.2018)

Görsel 13. Andreas Serrano, Morg (AIDS iliş̧kili Ölüm), 1992. http://www.marthagarzon com/contemporary art/2012/10/body-and-spirit-andres-serrano/ (Erişim Tarihi:

13.04.2018) 